\title{
Do Men and Women in Saudi Arabia Have the Same Level of Awareness and Knowledge of Breast Cancer? A Cross-Sectional Study
}

This article was published in the following Dove Press journal: Breast Cancer: Targets and Therapy

\author{
Nada J Farsi (D' \\ Rolina Al-Wassia ${ }^{2}$ \\ Leena Merdad (D) \\ 'Department of Dental Public Health, \\ Faculty of Dentistry, King Abdulaziz \\ University, Jeddah, Saudi Arabia; \\ ${ }^{2}$ Department of Radiology, Faculty of \\ Medicine, King Abdulaziz University, \\ Jeddah, Saudi Arabia
}

Context: Awareness is important in combating breast cancer, as early detection (through mammograms) and prompt treatment offer the greatest chance of long-term survival.

Aims: The aim of this study was to assess public knowledge of breast cancer (signs, symptoms, and risk factors) and awareness of screening programs; and compare it among men and women.

Materials and Methods: A cross-sectional study was conducted among male and female residents of five of the geographic regions of Saudi Arabia from February 2015 to May 2015. Information was collected using a questionnaire, and included sociodemographic data, general knowledge about breast cancer, and awareness of screening programs. Chi-square $\mathrm{d}$ test was used to compare the binary knowledge variables (correct/incorrect) between men and women. Logistic regression was utilized to assess predictors of breast cancer knowledge. Results: A total of 9691 men and 31,022 women were surveyed. Women had better knowledge regarding breast cancer symptoms than men, except for breast cancer being related to death. Men and women had similar knowledge of breast cancer risk factors; however, more women correctly identified family history $(68 \%)$, large breast size $(46 \%)$ as increasing risk, and breastfeeding $(60 \%)$ as reducing the risk of breast cancer compared to men (56\%, 32\%, and $47 \%$, respectively). Older age and higher education were related with high breast cancer knowledge, and it was more pronounced among men. Employment was a predictor for better knowledge among women. Participants with no history of breast cancer were less likely to have good breast cancer knowledge compared with those with a family history, (OR: 0.5, 95\% CI: 0.5-0.6) and (OR: 0.6, 95\% CI: 0.5-0.6) among men and women, respectively. More women (24\%) than men (19\%) knew of breast cancer screening programs, although the awareness was low in both genders.

Conclusion: Awareness campaigns in Saudi Arabia, especially those aimed at men, remain critical to increase knowledge and change behavior toward early detection of breast cancer.

Keywords: breast cancer, knowledge, screening, awareness

\section{Introduction}

Breast cancer is one of the leading causes of death among women, accounting for $24 \%$ of all female cancer cases diagnosed in Saudi Arabia each year. ${ }^{1}$ The incidence of breast cancer in Saudi Arabia is increasing and occurs at a younger age compared to western countries. ${ }^{2}$ Awareness is extremely important in combating this disease, as early detection and prompt treatment offers the greatest chance of long-term survival. ${ }^{3}$ Therefore, assessing the level of knowledge and awareness of this disease in Saudi Arabia is key.
Correspondence: Nada J Farsi

Department of Dental Public Health, Faculty of Dentistry, King Abdulaziz

University, P.O. Box 80215, Jeddah 21589,

Saudi Arabia

Tel +966126400000

Fax+966126952437

Email njfarsi@kau.edu.sa
Breast Cancer: Targets and Therapy 2020:12 131-139

submit your manuscript DovePress if in $>$ http://doi.org// 0.2147/BCTT.S262544 
Although knowledge of breast cancer and screening among women in Saudi Arabia is weak, it is also important to consider that in patriarchal societies (such as Saudi Arabia, Ghana, South Africa, and Kenya), men are often the primary decision-makers. Therefore, their knowledge can have a major influence on decisions regarding women's health care. ${ }^{4-6}$ This is because men will often influence behaviors regarding allocation of money, transport, and time that women can use to access health-care services. ${ }^{4-7}$ For example, a recent study in Ghana found that few men are actively involved in issues of maternal health care, which limits women's access to skilled health-care services. ${ }^{4}$ Indeed, there is increasing evidence that improving men's knowledge and awareness of maternal health issues can benefit health outcomes among women. ${ }^{8-10}$ Therefore, assessing knowledge of breast cancer among men in Saudi Arabia is important. Unfortunately, few studies have examined this issue to date. ${ }^{11,12}$

To the best of our knowledge, only one study has been conducted among adult Saudi men, which included 550 participants who attended the outpatient clinics of King Abdulaziz University Hospital with their female relatives. ${ }^{11}$ Similar to the data reported for adult Saudi women, this study showed that men had poor knowledge of breast cancer symptoms, and only $57.6 \%$ were aware of the importance of early detection. ${ }^{11}$ Furthermore, a crosssectional report on 824 Saudi male high school students in Jeddah (mean age $=17$ years) indicated that while two thirds of male students knew that early detection of breast cancer was important, the level of knowledge of breast cancer risk factors among young Saudi men was poor (eg, only 57.9\% stated that breast cancer was inherited). ${ }^{12}$ Therefore, based on limited available data, knowledge of breast cancer among Saudi men appears to be at a low level.

To date, no single study has directly compared knowledge and awareness of breast cancer among adult Saudi men and women, including women who are at the age where mammograms are required. The aim of this study was to address this gap in the literature by comparing the knowledge of breast cancer, its signs and symptoms, its risk factors, and the awareness of screening programs across a sample of men and women from the five main geographic regions in Saudi Arabia.

\section{Materials and Methods}

\section{Study Design and Data Collection}

A cross-sectional study was conducted among male and female residents of five of the geographic regions of Saudi
Arabia: North, South, East, West, and Central. Questionnaires were distributed electronically through social media platforms. In addition, paper forms of the questionnaire were distributed in the main local shopping malls in each geographic region. They were also distributed in secondary schools and universities to faculty members and students. The data were collected from February 2015 to May 2015.

\section{Ethical Considerations}

A cover letter containing a brief description of the study and its aim was included in the questionnaire, and it was written that participation was voluntary. Participants were informed that completing the questionnaire indicates their consent to participate in the study. Ethical approval was obtained from the Unit of Biomedical Ethics and Research Committee of the Faculty of Medicine in King Abdulaziz University (reference no. 51-15).

\section{The Questionnaire}

A standardized questionnaire was developed based on previous questionnaires used to investigate breast cancer and mammography knowledge, ${ }^{13}$ and other relevant questions were added after searching the literature. ${ }^{13}$ Experts from various medical fields (oncology, radiology, surgery, and radiation oncology) revised the questionnaire to ensure its relevance and comprehensibility. The questionnaire was designed to assess knowledge about and attitudes towards mammography and breast cancer. It contained five sections: (i) sociodemographic information, (ii) general knowledge about breast cancer and its risk factors, (iii) knowledge about mammography and its use, (iv) barriers to mammography use, and (v) knowledge of breast cancer awareness and screening programs. In this article, the sections concerning sociodemographic information, breast cancer knowledge and its risk factors, and breast cancer awareness and screening programs are assessed.

The following questions were used to assess general knowledge about breast cancer and its symptoms: "Is breast cancer widely spread in Saudi Arabia?", "Is breast cancer associated with death?", "Can breast cancer be inherited?", "Can early detection of breast cancer improve the outcome of treatment?", and "Is a mass or swelling in the breast or armpit related to breast cancer?". To assess the participants' knowledge of breast cancer risk factors, they were asked what the effect of the following were on 
the possibility of a woman developing breast cancer: aging, first delivery above age 30 years, smoking, obesity, use of oral contraceptives, family history of breast cancer, puberty below the age of 11 years, breastfeeding, large breast size, and menopause after 55 years. Three questions were asked in the awareness of campaigns and screening programs section, including: " Do you think there are enough breast cancer awareness campaigns in Saudi Arabia?", "how do you evaluate awareness of breast cancer in our society?", and "are you aware of breast cancer screening programs in Saudi Arabia?".

\section{Statistical Analyses}

The sociodemographic characteristics of the participants were presented as frequencies and percentages. The general breast cancer knowledge questions had the following response options: "yes," “no," “don't know." The risk factor knowledge questions had the following response options: "increases risk," "decreases risk," "no effect on risk," “don't know". These responses were recategorized into two categories: 0: correct, which included the correct answer, and 1: incorrect, which included the wrong answers and "don't know" responses. The binary knowledge variables were presented as frequency distributions for all participants and stratified by gender. Chi-squared tests were used to compare the binary knowledge variables (correct/incorrect) between men and women.

The sum of the responses of the breast cancer knowledge questions was used to create a breast cancer knowledge score, which ranged from 0 to 5 . The median of the score variable was used to categorize it into: low knowledge (0-3), and high knowledge (4-5). The predictors of breast cancer knowledge were assessed by a logistic regression, and $\mathrm{OR}$ and $95 \% \mathrm{CI}$ were estimated for each variable. The following variables were assessed as independent variables: age, number of children, marital status, occupation, education, family income, and family history of breast cancer.

Frequency distributions were also produced for participant's perceptions about breast cancer awareness and campaigns in Saudi Arabia for all subjects and stratified by gender. Chi-squared tests were used to compare the responses between men and women. A $p$-value of $<0.05$ was considered statistically significant. Data analyses were conducted using Stata version 13.0 (StataCorp LP, College Station, TX, USA).

\section{Results}

A total of 40,859 participants were included in this study. We excluded 146 participants from the current analyses because of missing information on gender, resulting in 9691 men and 31,022 women. As Table 1 shows, approximately $70 \%$ of the participants were younger than 31 years old, and 76\% were women. Most men (92\%) and women $(92 \%)$ were educated to high school level or above. More than half of the male participants were employed $(57 \%)$ compared to $27 \%$ of women. Approximately $70 \%$ of participants had an income below 16,000 SAR per month (67\% of men and $70 \%$ of women). Most participants had either no previous family history of breast cancer $(72 \%)$ or were unsure $(10 \%)$.

Table 2 shows the responses of the participants to general knowledge questions about breast cancer and its symptoms. The majority of participants (91\%) knew that early detection of breast cancer improves treatment outcomes, and that breast cancer is widespread in Saudi Arabia (72\%). A large percentage of participants recognized that a mass or swelling in the breast or armpit is related to breast cancer $(81 \%)$. Around half of the participants reported that these cancers are associated with death (54\%), and that they can be inherited (50\%). A significantly higher percentage of women answered the questions correctly compared with men $(p<0.01)$, except for the association of breast cancer with death, where more men $(56 \%)$ than women $(54 \%)$ answered correctly.

Table 3 shows the participants' responses to questions about breast cancer risk factors. The majority of participants correctly reported that smoking is a risk factor for breast cancer (72\%). A total of $65 \%$ and $60 \%$ of participants were aware that a family history of breast cancer and aging are risk factors, respectively. Breastfeeding was correctly recognized by $57 \%$ of the participants to reduce the risk of breast cancer. About half of the participants identified obesity (52\%) and contraceptive use (48\%) as breast cancer risk factors. Large breast size was correctly recognized to have no effect on breast cancer by $43 \%$ of the participants. Slightly more than $30 \%$ correctly reported that the first delivery above age 30 years and menopause after age 55 years are breast cancer risk factors, while only $18 \%$ of the participants correctly reported that experiencing puberty below age 11 years is a risk factor. A significantly larger percentage of women than men correctly identified most of the breast cancer risk factors in this study. However, more men 
Table I Socio-Demographic Characteristics of Participants

\begin{tabular}{|c|c|c|c|}
\hline $\begin{array}{l}\text { Sociodemographic } \\
\text { Variables }\end{array}$ & $\begin{array}{l}\text { Total } \\
\text { n (\%) }\end{array}$ & $\begin{array}{l}\text { Men } \\
n(\%)\end{array}$ & $\begin{array}{l}\text { Women } \\
\text { n (\%) }\end{array}$ \\
\hline Total & 40,713 & 9691 & 31,022 \\
\hline \multicolumn{4}{|l|}{ Age } \\
\hline$<20$ & $|I, 63|(29)$ & $1929(20)$ & $9702(31)$ \\
\hline $21-30$ & $|6,23|(40)$ & $3849(40)$ & $12,382(40)$ \\
\hline $3 I-40$ & $8052(20)$ & $2359(24)$ & $5693(18)$ \\
\hline $40+$ & 4654 (II) & $1536(16)$ & $3118(10)$ \\
\hline \multicolumn{4}{|l|}{ Number of children } \\
\hline No children & $24,432(6 I)$ & $5181(54)$ & $|9,25|(63)$ \\
\hline One or more children & 15,840 (39) & $4406(46)$ & II,434 (37) \\
\hline \multicolumn{4}{|l|}{ Marital status } \\
\hline Married & $16,975(42)$ & $4697(49)$ & $12,278(40)$ \\
\hline Single & $21,479(53)$ & $4468(46)$ & $|7,0| \mid(55)$ \\
\hline Widowed/divorced & $2076(5)$ & $488(5)$ & $1588(5)$ \\
\hline \multicolumn{4}{|l|}{ Occupation } \\
\hline Unemployed & 3729 (39) & 3729 (39) & $21,898(71)$ \\
\hline Employed & $5505(57)$ & $5505(57)$ & $8345(27)$ \\
\hline Retired & $348(4)$ & $348(4)$ & $541(2)$ \\
\hline \multicolumn{4}{|l|}{ Education } \\
\hline Below high school & $3320(8)$ & $795(8)$ & $2525(8)$ \\
\hline High school/diploma & 15,597 (39) & $3940(4 I)$ & II,657 (38) \\
\hline University & $19,020(47)$ & $3982(4 I)$ & $15,038(49)$ \\
\hline Postgraduate & $2588(6)$ & $920(10)$ & $1668(5)$ \\
\hline \multicolumn{4}{|l|}{$\begin{array}{l}\text { Family income (SAR/ } \\
\text { month) }\end{array}$} \\
\hline$<8000$ & $11,956(30)$ & $2730(29)$ & $9226(31)$ \\
\hline $9000-15,000$ & $15,288(39)$ & $3618(38)$ & II,670 (39) \\
\hline $16,000-25,000$ & $7983(20)$ & $2050(22)$ & $5933(20)$ \\
\hline$>26,000$ & $4 \mid 47$ (II) & $1136(12)$ & $3011(10)$ \\
\hline \multicolumn{4}{|l|}{ Region } \\
\hline Western & $10,586(26)$ & $2705(28)$ & $788 \mid(26)$ \\
\hline Eastern & $6653(16)$ & $|40|(15)$ & $5252(17)$ \\
\hline Central & $10,524(26)$ & $1944(20)$ & $8580(28)$ \\
\hline Northern & $5469(14)$ & $1622(17)$ & 3847 (12) \\
\hline Southern & $7200(18)$ & $1970(20)$ & $5230(17)$ \\
\hline \multicolumn{4}{|l|}{$\begin{array}{l}\text { Family history of } \\
\text { breast cancer }\end{array}$} \\
\hline Yes & 7178 (18) & $1532(16)$ & $5646(18)$ \\
\hline No & $28,752(72)$ & 6712 (7I) & $22,040(72)$ \\
\hline I do not know & $4185(10)$ & |27| (13) & $2914(10)$ \\
\hline
\end{tabular}

recognized that the first delivery above age 30 years $(35 \%)$ and obesity (54\%) are risk factors for breast cancer compared to $33 \%$ and $51 \%$ of women, respectively. There was no statistically significant difference between men and women in identifying puberty below 11 years of age as a risk factor for breast cancer.
Table 4 illustrates the predictors of breast cancer knowledge among the participants stratified by gender. Participants of older age seemed to be more likely to have high knowledge about breast cancer, and this was more pronounced among men. In addition, divorced and widowed participants were less likely to have high breast cancer knowledge, compared with those who are married. Employment was a predictor for better knowledge among women, and worse knowledge among men. The higher the education level of the participants the more likely it was that they had good knowledge, and this was more pronounced among men. Among men, (OR: 2.2, 95\% CI: 1.7-2.7) and (OR: $3.095 \%$ CI: 2.3-3.8) for postgraduate and university attainers compared with participants with less than high a school degree, respectively. While among women, (OR: 1.4, 95\% CI: 1.3-1.5) and (OR: 1.4 95\% CI: 1.2-1.6) for those with postgraduate and university degrees, compared with participants with less than a high school degree, respectively. Participants with income higher than $8000 \mathrm{SAR} /$ month, were more likely to have good breast cancer knowledge. While, participants with no family history of breast cancer were less likely to have good knowledge.

The participants' perceptions about breast cancer awareness and campaigns in Saudi Arabia are summarized in Table 5. About half of the women (56\%) reported there are enough breast cancer awareness campaigns in Saudi Arabia, compared to $37 \%$ of men. Most participants (84\%) reported that the awareness of breast cancer in Saudi society is average to weak, compared with only $16 \%$ who believed it was excellent. More men (42\%) compared to women (22\%) reported that this awareness was weak. A lack of awareness of breast cancer screening programs in Saudi Arabia was reported by $77 \%$ of the participants. Significantly more women than men ( $24 \%$ vs $19 \%$, respectively; $p<0.01$ ) were aware of these programs.

\section{Discussion}

Men's knowledge of women's health care issues in patriarchal societies, such as Saudi Arabia, can affect women's access to relevant health care and screening programs. ${ }^{6,7,10}$ In this study, we found that the level of knowledge of breast cancer both among men and women in Saudi Arabia was poor; however, women had slightly better knowledge than men. Therefore, improving knowledge of breast cancer, particularly among men, may facilitate early detection of this disease. 
Table 2 Participants' Responses to General Knowledge Questions About Breast Cancer and its Symptoms

\begin{tabular}{|c|c|c|c|c|c|c|c|}
\hline \multirow[t]{2}{*}{ General Knowledge Questions } & \multicolumn{2}{|l|}{ Total n (\%) } & \multicolumn{2}{|l|}{ Men n (\%) } & \multicolumn{2}{|c|}{ Women n (\%) } & \multirow[t]{2}{*}{ p-value* } \\
\hline & Correct $^{\mathbf{a}}$ & $\begin{array}{l}\text { Incorrect/ } \\
\text { Do Not } \\
\text { Know }\end{array}$ & Correct $^{a}$ & $\begin{array}{l}\text { Incorrect/ } \\
\text { Do Not } \\
\text { Know }\end{array}$ & Correct $^{a}$ & $\begin{array}{l}\text { Incorrect/ } \\
\text { Do Not } \\
\text { Know }\end{array}$ & \\
\hline $\begin{array}{l}\text { Do you think that breast cancer is widely } \\
\text { spread in Saudi Arabia? }\end{array}$ & $29,205(72)$ & II,446 (28) & $6031(62)$ & $3646(38)$ & $23,174(75)$ & $7800(25)$ & $<0.001$ \\
\hline $\begin{array}{l}\text { Do you think that breast cancer is } \\
\text { associated with death? }\end{array}$ & $21,971(54)$ & $|8,65|(46)$ & $5404(56)$ & $4273(44)$ & $16,567(54)$ & $14,378(46)$ & $<0.001$ \\
\hline Can breast cancer be inherited? & $20,458(50)$ & $20,166(50)$ & $3980(4 I)$ & $5698(59)$ & $16,478(53)$ & $14,468(47)$ & $<0.001$ \\
\hline $\begin{array}{l}\text { Can early detection of breast cancer } \\
\text { improve the outcome of treatment? }\end{array}$ & $37,046(91)$ & $3545(9)$ & $8178(85)$ & 1495 (15) & $28,868(93)$ & $2050(7)$ & $<0.001$ \\
\hline $\begin{array}{l}\text { Do you think a mass or swelling in the } \\
\text { breast or the armpit is related to breast } \\
\text { cancer? }\end{array}$ & $32,759(81)$ & $7790(19)$ & $6447(67)$ & $3206(33)$ & $26,312(85)$ & $4584(15)$ & $<0.001$ \\
\hline
\end{tabular}

Notes: ${ }^{a}$ The correct answer is the "yes" response category. $*$ The $p$-value of differences between men and women.

Table 3 Participants' Responses to Questions About Breast Cancer Risk Factors

\begin{tabular}{|c|c|c|c|c|c|c|c|}
\hline \multirow{2}{*}{$\begin{array}{l}\text { What is the effect of the following on the } \\
\text { possibility of a woman developing breast } \\
\text { cancer? }\end{array}$} & \multicolumn{2}{|l|}{ Total n (\%) } & \multicolumn{2}{|c|}{ Men n (\%) } & \multicolumn{2}{|c|}{ Women n (\%) } & \multirow[t]{2}{*}{ p-value* } \\
\hline & Correct $^{a}$ & $\begin{array}{l}\text { Incorrect/ } \\
\text { Do Not } \\
\text { Know }\end{array}$ & Correct $^{a}$ & $\begin{array}{l}\text { Incorrect/ } \\
\text { Do Not } \\
\text { Know }\end{array}$ & Correct $^{a}$ & $\begin{array}{l}\text { Incorrect/ } \\
\text { Do Not } \\
\text { Know }\end{array}$ & \\
\hline Aging & $24,313(60)$ & $16,106(40)$ & $5647(59)$ & $3982(4 I)$ & $18,666(61)$ & $12,124(39)$ & $<0.001$ \\
\hline First delivery above age 30 years & $13,314(33)$ & $26,895(67)$ & $3307(35)$ & $6274(65)$ & $10,007(33)$ & $20,621(67)$ & $<0.001$ \\
\hline Smoking & $29,142(72)$ & II,234 (28) & $6619(69)$ & $2998(31)$ & $22,523(73)$ & $8236(27)$ & $<0.001$ \\
\hline Obesity & $20,782(52)$ & $19,366(48)$ & $5169(54)$ & $4424(46)$ & $15,613(5 \mid)$ & $14,942(49)$ & $<0.001$ \\
\hline Contraceptives use & $19,276(48)$ & $20,773(52)$ & $4320(45)$ & $5208(55)$ & $14,956(49)$ & $15,565(5 \mid)$ & $<0.001$ \\
\hline Family history of breast cancer & $26,293(65)$ & $13,936(35)$ & $5326(56)$ & $4262(44)$ & $20,967(68)$ & $9674(32)$ & $<0.001$ \\
\hline Puberty below II years & $7,040(18)$ & $33,084(82)$ & $1743(18)$ & $7801(82)$ & $5297(17)$ & $25,283(83)$ & 0.035 \\
\hline Breast feeding & 22,895 & $17,342(43)$ & 4507 (47) & $5043(53)$ & $18,388(60)$ & $12,299(40)$ & $<0.001$ \\
\hline Large breast size & $17,185(43)$ & $23,079(57)$ & $3103(32)$ & $6488(68)$ & $14,082(46)$ & $|6,59|(54)$ & $<0.001$ \\
\hline Menopause after age 55 & $|3,92|(34)$ & $26,455(66)$ & $3077(32)$ & $6537(68)$ & $10,844(35)$ & $19,918(65)$ & $<0.001$ \\
\hline
\end{tabular}

Notes: "The correct answer is the "increase" response category. The exceptions are breastfeeding and large breast size, where "decrease" and "no effect" are the correct response categories, respectively. ${ }^{*}$ The $p$-value of differences between men and women

With regard to breast cancer symptoms, we found that Saudi men had poorer knowledge than Saudi women. In particular, more women (85\%) than men $(67 \%)$ were aware that a mass in the breast or armpit was related to breast cancer. Meanwhile, Saudi women showed better knowledge regarding breast cancer symptoms than rural women in Iran, where most women did not know that changes in breast shape (88.2\%), dimpling of breast skin (72.3\%), and nipple discharge (69.6\%) are the main symptoms of breast cancer. ${ }^{14}$ However, these differences may have been due to the fact that the majority of the women in Iran had poor education and limited access to medical facilities compared to the women in our study, who were mostly educated. Indeed, knowledge of breast cancer was previously found to be suboptimal in men and women with poor education and low socioeconomic status in India, ${ }^{15}$ and women with less formal education in the US were more likely to have inaccurate knowledge concerning breast cancer. ${ }^{16}$

Previous studies have indicated poor knowledge of breast cancer risk factors among both genders in Saudi Arabia. ${ }^{12,17,18}$ For example, $59.5 \%$ of Saudi women respondents in Abha $(n=1140$; mean age $=33.6 \pm 11.9$ years) had poor level of knowledge regarding breast 
Table 4 Predictors of Breast Cancer Knowledge Among Men and Women

\begin{tabular}{|c|c|c|c|c|c|c|c|c|}
\hline \multirow[t]{2}{*}{ Variables } & \multicolumn{4}{|l|}{ Men } & \multicolumn{4}{|l|}{ Women } \\
\hline & $\begin{array}{l}\text { Low } \\
\text { Knowledge } \\
\text { n=5533 }\end{array}$ & $\begin{array}{l}\text { High } \\
\text { Knowledge } \\
\text { n=4086 }\end{array}$ & $\begin{array}{l}\text { Univariate } \\
\text { OR (95\% } \\
\text { CI) }\end{array}$ & $\begin{array}{l}\text { Multivariate } \\
\text { OR }(95 \% \mathrm{Cl})\end{array}$ & $\begin{array}{l}\text { Low } \\
\text { Knowledge } \\
n=13,222\end{array}$ & $\begin{array}{l}\text { High } \\
\text { Knowledge } \\
n=\mid 7,477\end{array}$ & $\begin{array}{l}\text { Univariate } \\
\text { OR }(95 \% \\
\text { CI) }\end{array}$ & $\begin{array}{l}\text { Multivariate } \\
\text { OR }(95 \% \mathrm{Cl})\end{array}$ \\
\hline \multicolumn{9}{|l|}{ Total } \\
\hline \multicolumn{9}{|l|}{ Age } \\
\hline$<20$ & $129 \mid$ & 615 & 1.00 & 1.00 & 4353 & 5222 & 1.00 & 1.00 \\
\hline $21-30$ & 2130 & 1700 & $1.7(1.5-1.9)$ & $1.5(1.3-1.7)$ & 5120 & 7164 & $1.2(1.1-1.2)$ & I.I (I.0-I.2) \\
\hline $31-40$ & 1282 & 1057 & I.7 (I.5-2.0) & $1.5(1.3-1.9)$ & 2382 & 3247 & I.I (I.I-I.2) & $1.0(0.9-1.2)$ \\
\hline $40+$ & 822 & 705 & $1.8(1.6-2.1)$ & $1.4(1.1-1.8)$ & 1298 & 1789 & I.I (I.I-1.2) & $1.0(0.9-1.2)$ \\
\hline \multicolumn{9}{|l|}{ Number of children } \\
\hline No children & 3045 & 2100 & 1.00 & 1.00 & 8,126 & 10,937 & 1.00 & 1.00 \\
\hline$\geq$ I child & 2440 & 1933 & I.I (I.I-I.2) & $1.0(0.8-1.1)$ & 4938 & 6384 & $1.0(0.9-1.0)$ & $0.9(0.8-1.0)$ \\
\hline \multicolumn{9}{|l|}{ Marital status } \\
\hline Married & 2566 & 2100 & 1.00 & 1.00 & 5256 & 5256 & 1.00 & 1.00 \\
\hline Single & 2631 & 1806 & $0.8(0.8-0.9)$ & $1.0(0.8-1.2)$ & 7184 & 9644 & $1.0(1.0-1.1)$ & I.I (I.0-I.2) \\
\hline Widowed/divorced & 313 & 169 & $0.7(0.5-0.8)$ & $0.7(0.5-0.9)$ & 713 & 858 & $0.9(0.8-1.0)$ & $0.9(0.8-1.0)$ \\
\hline \multicolumn{9}{|l|}{ Occupation } \\
\hline Unemployed & 2185 & 1512 & 1.00 & 1.00 & 9641 & 12,055 & 1.00 & 1.00 \\
\hline Employed & 3089 & 2381 & I.I (I.0-I.2) & $0.8(0.7-0.9)$ & 3,269 & 4974 & $1.2(1.2-1.3)$ & $1.2(1.1-1.3)$ \\
\hline Retired & 191 & 155 & I.2 (0.9-I.5) & $0.9(0.6-1.2)$ & 220 & 319 & $1.2(1.0-1.4)$ & $1.0(0.8-1.2)$ \\
\hline \multicolumn{9}{|l|}{ Education } \\
\hline$<$ High school & 588 & 194 & 1.00 & 1.00 & 1326 & $|15|$ & 1.00 & 1.00 \\
\hline High school/Diploma & $247 I$ & 1440 & $1.8(1.5-2.1)$ & $1.6(1.3-1.9)$ & 5205 & 6303 & $1.4(1.3-1.5)$ & I.3 (I.I-I.4) \\
\hline University & 2047 & 1911 & $2.8(2.4-3.4)$ & $2.2(1.7-2.7)$ & 6012 & 8910 & $1.7(1.6-1.9)$ & $\mathrm{I} .4(\mathrm{I} .3-\mathrm{I} .5)$ \\
\hline Postgraduate & 395 & 521 & $4.0(3.2-4.9)$ & $3.0(2.3-3.8)$ & 618 & 1047 & $2.0(1.7-2.2)$ & $1.4(1.2-1.6)$ \\
\hline \multicolumn{9}{|l|}{$\begin{array}{l}\text { Family income (SAR/ } \\
\text { month) }\end{array}$} \\
\hline$<8000$ & 1708 & 997 & 1.00 & 1.00 & 4488 & 4634 & 1.00 & 1.00 \\
\hline $9000-15,000$ & 2096 & 1505 & $1.2(1.1-1.4)$ & I.I (I.0-I.2) & 4893 & 6680 & $1.3(1.3-1.4)$ & $1.3(1.2-1.3)$ \\
\hline $16,000-25,000$ & 1091 & 949 & $1.5(1.3-1.7)$ & $1.4(1.2-1.6)$ & 2221 & 3673 & $1.6(1.5-1.7)$ & $1.5(1.4-1.6)$ \\
\hline$>26,000$ & 540 & 585 & $1.9(1.6-2.1)$ & $1.5(1.3-1.8)$ & 1105 & 1882 & $1.6(1.5-1.8)$ & $\mathrm{I} .5(\mathrm{I} .4-\mathrm{I} .7)$ \\
\hline \multicolumn{9}{|l|}{$\begin{array}{l}\text { Family history of } \\
\text { breast cancer }\end{array}$} \\
\hline Yes & 656 & 856 & 1.00 & 1.00 & 1762 & 3828 & 1.00 & 1.00 \\
\hline No & 3892 & 2781 & $0.5(0.5-0.6)$ & $0.5(0.5-0.6)$ & 9882 & 11,945 & $0.6(0.5-0.6)$ & $0.6(0.5-0.6)$ \\
\hline
\end{tabular}

cancer risk factors (ie, $<50 \%$ correctly identified risk factors such as contraceptive pills, hormone replacement therapy, and age). ${ }^{19}$ Similarly, a recent survey of 40 Saudi women in Makkah aged 25-65 years confirmed they had poor knowledge of breast cancer (only 10\% responded correctly to the questions on breast cancer risk factors). ${ }^{20}$ Moreover, a recent cross-sectional study among Saudi women in Madinah ( $\mathrm{n}=465$; mean age $=34.9$ years) confirmed they had poor knowledge of breast cancer ( $<50 \%$ reported correct answers to questions relating breast cancer risk factors). ${ }^{21}$ In a study conducted among
200 women residing in Jeddah, investigators found that women had poor knowledge about breast cancer and more than $50 \%$ identified family history as a risk factor of breast cancer. ${ }^{17}$ Two years later, the results from 764 questionnaires completed by Saudi women aged 20 to $>60$ years revealed that breast cancer and screening knowledge among Saudi women remained limited (eg, only 34\% of the respondents identified the recommended age for breast cancer screening). ${ }^{18}$ In the present study, more women than men correctly identified most of the breast cancer risk factors, although the differences between men and 
Table 5 Participants' Perceptions About Breast Cancer Awareness and Campaigns in Saudi Arabia

\begin{tabular}{|c|c|c|c|c|}
\hline Variable & $\begin{array}{l}\text { Total } \\
\text { n (\%) }\end{array}$ & $\begin{array}{l}\text { Men } \\
\text { n (\%) }\end{array}$ & $\begin{array}{l}\text { Women } \\
\text { n (\%) }\end{array}$ & p-value* \\
\hline \multicolumn{5}{|c|}{$\begin{array}{l}\text { Do you think there are enough breast cancer awareness } \\
\text { campaigns in Saudi Arabia? }\end{array}$} \\
\hline No & 13,594 & $4393(46)$ & 9201 (30) & $<0.001$ \\
\hline Yes & $20,8 \mid 8(52)$ & 3581 (37) & $17,237(56)$ & \\
\hline Do not know & $596 \mid(15)$ & $1669(17)$ & $4292(14)$ & \\
\hline \multicolumn{5}{|c|}{$\begin{array}{l}\text { How do you evaluate awareness of breast cancer in our } \\
\text { society? }\end{array}$} \\
\hline Excellent & $6613(16)$ & 1143 (I2) & $5470(18)$ & \\
\hline Average & $22,993(57)$ & $4408(46)$ & $18,585(60)$ & $<0.001$ \\
\hline Weak & $10,770(27)$ & $4088(42)$ & $6682(22)$ & \\
\hline \multicolumn{5}{|c|}{$\begin{array}{l}\text { Are you aware of breast cancer screening programs in Saudi } \\
\text { Arabia? }\end{array}$} \\
\hline No & $17,850(44)$ & $4672(48)$ & $13,178(43)$ & \\
\hline Yes & 9281 (23) & 1833 (19) & $7448(24)$ & $<0.001$ \\
\hline Do not know & $13,232(33)$ & 3135 (33) & $10,097(33)$ & \\
\hline
\end{tabular}

Note: *The $p$-value of differences between men and women.

women in their knowledge of these factors were small. Most participants correctly reported smoking (72\%), family history of breast cancer (65\%), and aging (60\%) as breast cancer risk factors; however, only $18 \%$ of the participants correctly reported that experiencing puberty below the age of 11 years is a risk factor. Our findings are consistent with a previous large population-based study, which indicated limited awareness of risk factors among women in Iran (eg, less than one third of the 2250 respondents recognized that age at menarche was a risk factor for breast cancer). ${ }^{22}$ Therefore, the level of knowledge of breast cancer risk factors both among men and women in Saudi Arabia could be improved.

In agreement with other studies, ${ }^{23}$ we found that higher socioeconomic status was related to better breast cancer knowledge, which is not surprising, as it is well known that higher socioeconomic status is related to more health self-awareness. ${ }^{24}$ This could even be reflected on mammography utilization, as higher socioeconomic status has been linked with more breast cancer screening. ${ }^{25}$

Mammography has been available in all regions of Saudi Arabia since $2005^{26}$ and in 2007, a nationwide breast cancer screening facility in Riyadh was established. ${ }^{27}$ However, only $19 \%$ of men and $24 \%$ of women in our study were aware of these breast cancer screening programs. Similarly, a recent study reported low rates of breast cancer screening in
Saudi Arabia, despite the fact that mammography is free and widely available. ${ }^{26}$ Furthermore, while breast cancer awareness campaigns are widespread in Saudi Arabia (eg, the "Think Pink" campaign), it has been reported that they are not providing sufficient knowledge about the disease. ${ }^{13}$ Indeed, only $37 \%$ of men and half of the women in this study $(56 \%)$ reported there are enough breast cancer awareness campaigns in Saudi Arabia. Therefore, more aggressive campaigns and approaches may need to be investigated (encompassing media, religious leaders, schools, among others) to inform men and women about breast cancer. ${ }^{26}$ Such a lack of awareness of public health issues seems to be a recurring theme in Saudi Arabia; for example, poor awareness of cervical cancer and its risk factors among Saudi women was recently reported. ${ }^{28}$ This highlights a general need for improved education on key public health matters in this country.

There are some limitations to our study. First, our study may not be fully representative of the Saudi population, as we primarily assessed individuals living in urban/cosmopolitan areas. Indeed, there may be differences in breast cancer awareness between rural and urban/cosmopolitan areas (eg, Riyadh or Jeddah), which were not examined in this study. Second, the use of social media for part of the survey could also have biased the outcomes, as these participants have access to the internet, which tends to be a key source of knowledge of health issues. Third, our study relied on voluntary participation and self-reported data. Consequently, our results may be biased if there are systematic differences between people who responded and those who did not.

\section{Conclusions}

Overall, knowledge regarding breast cancer remains limited among men and women in Saudi Arabia. Men appear to have slightly lower levels of knowledge of breast cancer symptoms and lower awareness of screening programs than women in this country. There is a need to implement awareness campaigns in Saudi Arabia, especially aimed at men, to increase knowledge and change behavior toward the early detection and cure of breast cancer.

\section{Data Sharing Statement}

Data can be shared upon request from the corresponding author. 


\section{Ethics Approval and Informed Consent}

A cover letter containing a brief description of the study and its aim was included in the questionnaire, and it was written that participation was voluntary. Participants were informed that completing the questionnaire indicates their consent to participate in the study. Ethical approval was obtained from the Unit of Biomedical Ethics and Research Committee of the Faculty of Medicine in King Abdulaziz University (reference no. 51-15).

\section{Acknowledgments}

We would like to thank Zaid Sayedalamin, Osama Almotairi, Kawther Alkamis, Duaa Albashrawi, and Heba Alsaffar for their efforts in data collection.

\section{Author Contributions}

All authors made a significant contribution to the work reported, whether that is in the conception, study design, execution, acquisition of data, analysis and interpretation, or in all these areas; took part in drafting, revising or critically reviewing the article; gave final approval of the version to be published; have agreed on the journal to which the article has been submitted; and agree to be accountable for all aspects of the work.

\section{Funding}

This project was funded by the Deanship of Scientific Research (DSR) at King Abdulaziz University, Jeddah, under grant no. (G-329-140-37).

\section{Disclosure}

The authors have no conflicts of interest to disclose in this work.

\section{References}

1. Alghamdi IG, Hussain II, Alghamdi MS, El-Sheemy MA. The incidence rate of female breast cancer in Saudi Arabia: an observational descriptive epidemiological analysis of data from Saudi Cancer Registry 20012008. Breast cancer. 2013;5:103-109.

2. Saggu S, Rehman H, Abbas ZK, Ansari AA. Recent incidence and descriptive epidemiological survey of breast cancer in Saudi Arabia. Saudi Med J. 2015;36:1176-1180. doi:10.15537/smj. 2015.10.12268

3. Gotzsche PC, Nielsen M. Screening for breast cancer with mammography. Cochrane database syst rev. 2011;Cd001877.

4. Ganle JK, Dery I. 'What men don't know can hurt women's health': a qualitative study of the barriers to and opportunities for men's involvement in maternal healthcare in Ghana. Reprod Health. 2015;12:93. doi:10.1186/s12978-015-0083-y
5. Ganle JK, Obeng B, Segbefia AY, Mwinyuri V, Yeboah JY, Baatiema L. How intra-familial decision-making affects women's access to, and use of maternal healthcare services in Ghana: a qualitative study. BMC Pregnancy Childbirth. 2015;15:173. doi:10.1186/s12884-015-0590-4

6. Kwambai TK, Dellicour S, Desai M, et al. Perspectives of men on antenatal and delivery care service utilisation in rural western Kenya: a qualitative study. BMC Pregnancy Childbirth. 2013;13:134. doi:10.1186/1471-2393-13-134

7. Ganle JK, Parker M, Fitzpatrick R, Otupiri E. A qualitative study of health system barriers to accessibility and utilization of maternal and newborn healthcare services in Ghana after user-fee abolition. BMC Pregnancy Childbirth. 2014;14:425. doi:10.1186/s12884-014-0425-8

8. August F, Pembe AB, Mpembeni R, Axemo P, Darj E. Community health workers can improve male involvement in maternal health: evidence from rural Tanzania. Glob Health Action. 2016;9:30064. doi:10.3402/gha.v9.30064

9. Nyondo AL, Choko AT, Chimwaza AF, Muula AS. Invitation cards during pregnancy enhance male partner involvement in prevention of mother to child transmission (PMTCT) of human immunodeficiency virus (HIV) in Blantyre, Malawi: a randomized controlled open label trial. PLoS One. 2015;10:e0119273. doi:10.1371/journal.pone.0119273

10. Yargawa J, Leonardi-Bee J. Male involvement and maternal health outcomes: systematic review and meta-analysis. $J$ Epidemiol Community Health. 2015;69:604-612. doi:10.1136/jech-2014-204784

11. Al-Amoudi SM, Abduljabbar HS. Men's knowledge and attitude towards breast cancer in Saudi Arabia a cross-sectional study. Saudi Med J. 2012;33:547-550.

12. Al-Amoudi S, AlHomied MTA, AlSayegh NYN, et al. Breast Cancer Knowledge Among Male High School Students in Saudi Arabia. J Cancer Educ. 2016;31:784-788. doi:10.1007/s13187-015-0951-8

13. Hagi SK, Khafaji MA. Do women in Saudi Arabia "Think Pink"? Am J Res Commun. 2013;1:16.

14. Balouchi A, Shahdadi H, AlKhasawneh E, et al. Rural Women's Awareness about Breast Cancer in Southeastern Iran: a CrossSectional Study. Asian Pac J Cancer Prev. 2016;17:1875-1879. doi:10.7314/APJCP.2016.17.4.1875

15. Dey S, Mishra A, Govil J. Breast Cancer Awareness at the Community Level among Women in Delhi, India. Asian Pac J Cancer Prev. 2015;16:5243-5251. doi:10.7314/APJCP.2015.16.13.5243

16. White-Means S, Dapremont J, Rice M, Davis B, Stoddard O. Breast cancer mortality disparities: providers' perspective. J Nurs Educ Pract. 2017;7:46. doi:10.5430/jnep.v7n6p46

17. Radi SM. Breast Cancer awareness among Saudi females in Jeddah. Asian Pac J Cancer Prev. 2013;14:4307-4312. doi:10.7314/ APJCP.2013.14.7.4307

18. Abdallah A, El-Gharabawy R, Al-Suhaibany H. Knowledge, attitude and practice about breast cancer among women in Saudi Arabia. Int Arch Med. 2015. doi:10.3823/1847

19. Mahfouz AA, Hassanein MH, Nahar S, et al. Breast cancer knowledge and related behaviors among women in Abha City, southwestern Saudi Arabia. J Cancer Educ. 2013;28:516-520. doi:10.1007/ s13187-013-0495-8

20. Nageeti TH, Abdelhameed AAN, Jastania RA, Felemban RM. Perspective of Saudi women in the Makkah region on breast cancer awareness. J Family Community Med. 2017;24:97-101.

21. Al-Zalabani AH, Alharbi KD, Fallatah NI, Alqabshawi RI, AlZalabani AA, Alghamdi SM. Breast Cancer Knowledge and Screening Practice and Barriers Among Women in Madinah, Saudi Arabia. J Cancer Educ. 2018;33:201-207. doi:10.1007/s13187-0161057-7

22. Tazhibi M, Feizi A. Awareness levels about breast cancer risk factors, early warning signs, and screening and therapeutic approaches among Iranian adult women: a large population based study using latent class analysis. Biomed Res Int. 2014;2014:306352. doi:10.1155/ 2014/306352 
23. Aydogan U, Doganer YC, Kilbas Z, et al. Predictors of knowledge level and awareness towards breast cancer among Turkish females. Asian Pac J Cancer Prev. 2015;16:275-282. doi:10.7314/APJCP.2015.16.1.275

24. Feinstein JS. The relationship between socioeconomic status and health: a review of the literature. Milbank Q. 1993;71:279-322. doi: $10.2307 / 3350401$

25. Donnelly TT, Al Khater AH, Al Kuwari MG, et al. Do socioeconomic factors influence breast cancer screening practices among Arab women in Qatar? BMJ Open. 2015;5:e005596. doi:10.1136/bmjopen2014-005596
26. El Bcheraoui C, Basulaiman M, Wilson S, et al. Breast cancer screening in Saudi Arabia: free but almost no takers. PLoS One. 2015;10:e0119051. doi:10.1371/journal.pone.0119051

27. Abulkhair OA, Al Tahan FM, Young SE, Musaad SM, Jazieh AR. The first national public breast cancer screening program in Saudi Arabia. Ann Saudi Med. 2010;30:350-357.

28. Al-Shaikh GK, Almussaed EM, Fayed AA, et al. Knowledge of Saudi female university students regarding cervical cancer and acceptance of the human papilloma virus vaccine. Saudi Med J. 2014;35:1223-1230.

\section{Publish your work in this journal}

Breast Cancer - Targets and Therapy is an international, peer-reviewed open access journal focusing on breast cancer research, identification of therapeutic targets and the optimal use of preventative and integrated treatment interventions to achieve improved outcomes, enhanced survival and quality of life for the cancer patient.
The manuscript management system is completely online and includes a very quick and fair peer-review system, which is all easy to use. Visit http://www.dovepress.com/testimonials.php to read real quotes from published authors. 